\title{
Sebaran Sedimen Dasar di Perairan Karimunjawa
}

\author{
Larosa Nurfikri Gamellia ${ }^{1}$, Purwanto ${ }^{1}$, Sugeng Widada ${ }^{1}$, Petrus Subardjo ${ }^{1}$, Muslim ${ }^{1}$, Rikha \\ Widiaratih $^{1}$
}

\author{
${ }^{1}$ Departemen Oseanografi, Fakultas Perikanan dan Ilmu Kelautan, Universitas Diponegoro \\ Jl. Prof. Sudarto, SH Tembalang Tlp. / Fax. (024)7474698 Semarang 50275 \\ Email corresponding author: larosanurfikrigameliya13@gmail.com
}

\begin{abstract}
Abstrak
Bangunan terumbu buatan (Artificialreefs) merupakan salah satu bentuk upaya untuk menganggulangi dan rehabilitasi kerusakan yang terjadi pada terumbu karang alami. Pembuatan terumbu buatan merupakan suatu rekayasa struktur bangunan yang sengaja diturunkan ke laut untuk menyerupai habitat ikan dan ekosistem terumbu karang. Adanya bangunan tersebut dapat mempengaruhi dinamika faktor hidro-oseanografi yang terjadi, salah satunya yaitu proses sedimentasi yang dipengaruhi oleh arus laut. Tujuan penelitian ini adalah untuk mengetahui distribusi sebaran sedimen dasar yang terjadi pada bangunan terumbu buatan (artificial reefs) pada saat sebelum dan sesudah simulasi model. Penelitian ini dibagi dalam dua tahap yaitu tahap survei lapangan dan tahap pemodelan numerik menggunakan MIKE 21 flow model serta dilanjutkan modul Sand Transport (ST). Metode penelitian ini menggunakan metode kuantitatif dan penentuan lokasi penelitian dipilih secara purposive sample. Hasil penelitian menunjukkan kondisi hidrodinamika pada lokasi penelitian dengan kecepatan arus maksimum sebesar $0.9388 \mathrm{~m} / \mathrm{sdengan}$ arah dominan menuju barat laut dan timur laut. Analisa sedimentasi dilakukan dengan mengamati hasil dari model (output) serta membuat potongan melintang pada daerah struktur bangunan dan membandingkan hasil baik sebelum maupun setelah simulasi. Hasil potongan melintang I-I' dan potongan melintang II-II' mengalami perubahan kedalaman (erosi) sepanjang garis potongan melintang, sedangkan pada potongan melintang III-III' mengalami penumpukan material sedimen (sedimentasi) pada rentang jarak $10 \mathrm{~m}$.
\end{abstract}

Kata kunci: Terumbu Buatan, Sedimentasi, Model Hidrodinamika, Model Sand Transport, Perairan Batu Putih Karimunjawa.

Abstract

Artificial reefs (Artificial reefs) are one of method for overcome and rehabilitate damages that occurs on natural reefs. The manufacture of artificial reefs is a structural engineering that deliberately lowered to the sea to resemble the habitat of fishes and coral reef ecosystem. The existence of such buildings can affect the dynamics of hydro-oceanography factors that occur, for example the sedimentation process which influenced by the ocean currents. This study was purposed to determine the distribution pattern of sedimentation process that occurs on the building of artificial reefs, before and after the model simulation. This study was divided into two phases, field survey phase and numerical modelling using MIKE 21 flow model module continued with Sand Transport module (ST). This study used a quantitative method and determination of location was using purposive sampling method. The result shown hydrodinamic condition of study location with maximum velocity rate at $0,9388 \mathrm{~m} / \mathrm{s}$, dominantly went to northwest and northeast. For sedimentation analysis was done by observing the results of the model (output) and also making a cross section on the area of the building structure and compare the results both before and after simulation. The I-I' cross section and II-II' cross section had and increase in depth (erosion) across the cross section line, and then in a section III-III' there is a sediment buildup (sedimentation) in the range of 10 meters.

Keywords: Artificial Reefs, Sea Current, Sedimentation, Hydrodinamic model, Sand Transport Model, Batu Putih Waters, Karimunjawa 


\section{PENDAHULUAN}

Kepulauan Karimunjawa terletak di sebelah barat laut Kabupaten Jepara, Jawa Tengah dengan jarak sekitar 45 mil atau $83 \mathrm{~km}$. Secara geografis Kepulauan Karimunjawa terletak dalam koordinat $5^{\circ} 40^{\prime}-5^{\circ} 71^{\prime}$ LU dan $110^{\circ} 4^{\prime}-110^{\circ} 41^{\prime}$ BT dan berada pada ketinggian 65-500 m dari permukaan laut. Menurut Umardiono (2011), luas dari wilayahnya yaitu sebesar 111.625 ha yang terdiri dari 7.033 ha daratan dan 104.592 ha perairan. Tahun 1988 yang tertuang dalam Surat Keputusan Menteri Kehutanan No.161/Menhut-II/1988, Kepulauan Karimunjawa ditetapkan sebagai kawasan Taman Nasional Laut yang memiliki fungsi utama yaitu sebagai kawasan konservasi (Yusuf et al, 2012).

Perairan Kepulauan Karimunjawa memiliki karakteristik yang spesifik baik secara geografis maupun ekologis. Kawasan perairan Kepulauan Karimunjawa merupakan tipe perairan semi tertutup. Perairan tersebut dikelilingi oleh gugusan pulau-pulau yang merupakan daerah dengan ekosistem terumbu karang tersebar luas dan merata, yang dapat melindungi pantai dari hempasan gelombang dan menahan kuatnya arus yang menuju pantai (Yusuf, 2007 dalam Yusuf et al., 2012).

Daya tarik utama kawasan perairan Kepulauan Karimunjawa terletak pada ekosistem terumbu karang sebagai objek wisata bahari. Terdapat hubungan antara persen tutupan karang dengan pemanfaatan suatu lokasi, dimana pada saat pemanfaatan yang cukup tinggi maka perairan cenderung memiliki tutupan karang yang rendah (Juhasz et al., 2010).

Bangunan terumbu buatan (artificialreefs) merupakan salah satu bentuk upaya untuk menganggulangi dan rehabilitasi kerusakan yang terjadi pada terumbu karang alami. Pembuatan terumbu buatan merupakan suatu rekayasa struktur bangunan yang sengaja diturunkan ke laut untuk menyerupai habitat ikan dan ekosistem terumbu karang. Bangunan terumbu buatan yang terletak di perairan Batu Putih, berada pada sisi timur Pulau Kemujan dan sisi barat antara Pulau Tengah dan Pulau Cilik. Terumbu buatan tersebut terdiri dari beberapa komponen yang meliputi, blok beton, berbagai bangunan rumah ikan (fish shelter) dan blok beton setinggi 3 meter yang terdapat meja transplantasi karang dengan diameter 3 meter.

Bangunan terumbu buatan tersebut dapat mempengaruhi dinamika faktor hidro-oseanografi yang terjadi. Berdasarkan data Balitbang (2003), perairan Kepulauan Karimunjawa termasuk ke dalam Musim Timur dan Musim Barat serta dua musim Peralihan yakni Musim Peralihan I dan Peralihan II. Menurut Nontji (1993), musim tersebut dipengaruhi oleh sifat perairan seperti arus laut yang mengalir dari barat ke timur (musim barat), sedangkan jika terjadi arus laut yang mengalir dari timur ke barat (musim timur). Beberapa faktor hidro-oseanografi yang terjadi karena adanya bangunan terumbu buatan tersebut salah satunya adalah proses sedimentasi.

Sedimentasi merupakan peristiwa pengendapan material batuan yang diangkut oleh tenaga air atau angin. Menurut Rifardi (2012), faktor sedimentasi yang mempengaruhi paling dominan adalah arus, yang akan mengangkut sedimen dan mempengaruhi distribusinya. Penelitian ini akan dilakukan pemodelan arus dan pemodelan transport sedimen dasar. Analisa ukuran butir sedimen juga dilakukan untuk mengetahui jenis sedimen dasar dan distribusi sedimen dasar pada bangunan terumbu buatandi perairan Batu Putih Karimunjawa. Peta lokasi penelitian dapat dilihat pada (Gambar 1). 


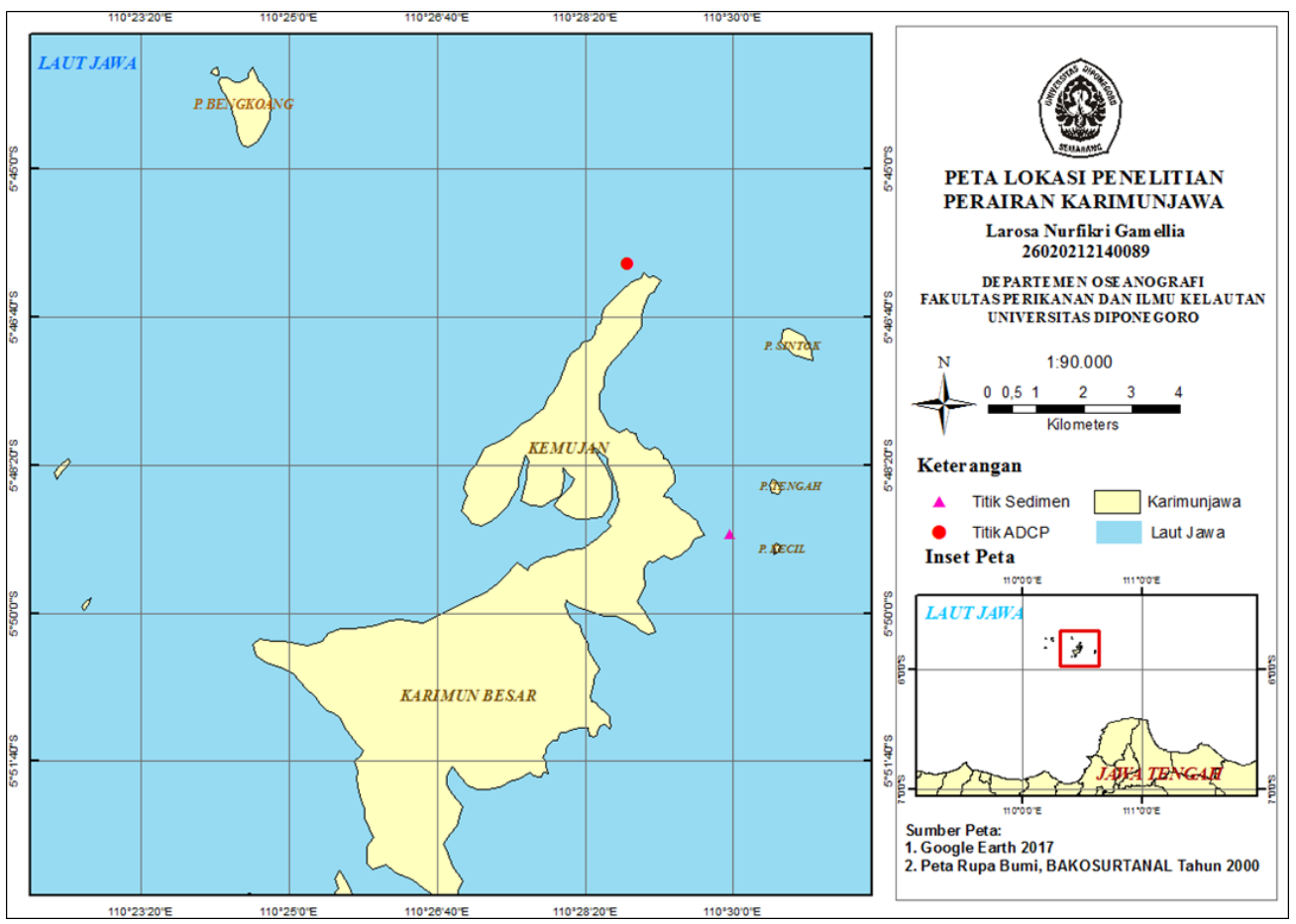

Gambar 1. Peta Lokasi Penelitian

\section{MATERI DAN METODE}

Materi pada penelitian ini adalah berupa data utama (primer) maupun data pendukung (sekunder). Data utama yang digunakan dalam penelitian ini adalah data sedimen dasar dan data arus, sedangkan untuk data pendukung dalam penelitian ini adalah Peta Bathimetri Karimunjawa DISHIDROS 1:100.000 yang digunakan sebagai input setting model.

Metode penelitian yang digunakan adalah metode kuantitatif, metode kuantitatif ialah sebuah metode ilmiah yang telah memenuhi kaidah-kaidah ilmiah yaitu konkrit, objektif, terukur, rasional dan sistematis. Data penelitian dalam metode ini berupa angka-angka dan analisa menggunakan statistik atau model. Berdasarkan tujuannya penelitian ini menggunakan penelitian pengembangan, sedangkan berdasarkan tingkat kealamiahan tempat, penelitian ini menggunakan penelitian survey (Sugiyono, 2014).

Pengukuran arus dilakukan menggunakan metode Eulerian yaitu dengan alat ukur diam yang diletakan di dasar perairan, sehingga alat dapat merekam partikel air yang melintas diatas alat tersebut. Alat pengukuran arus dalam penelitian menggunakan ADCP untuk mendapatkan data arah dan kecepatan arus absolut pada berbagai kedalaman.

Pengambilan data sedimen dasar menggunakan grab sampler sediment di daerah bangunan terumbu buatan. Lokasi pengambilan data sedimen berada pada koordinat5 $5^{\circ} 48^{\prime} 57.823^{\prime \prime}$ LS dan $110^{\circ} 30^{\prime} 7.02^{\prime \prime}$ BT.

Data hasil perekaman ADCP adalah kecepatan vectoru dan $v$, kecepatan total dan arahnya beserta waktu interval 10 menit. Pengolahan data arus disajikan dan digunakan sebagai data verifikasi dalam melakukan validasi numerik.

Sampel sedimen basah di keringkan terlebih dahulu, kemudian dilakukan analisa ukuran butir sedimen dasar menggunakan metode Buchanan yaitu pengayakan dan pipeting. Setelah metode analisa ukuran butir sedimen selesai dilakukan, hasil yang didapat kemudian diplotkan dalam sieve graph dan dilakukan penamaan sesuai dengan segitiga penamaan sedimen.

Model numerik yang digunakan dalam simulasi model hidrodinamika adalah Flow Model pada software MIKE 21. Penelitian dalam tahap ini dilakukan dengan membangun 2 bentuk daerah domain, yaitu domain besar yang digunakan untuk verifikasi data arus lapangan serta domain kecil yang digunakan untuk modul Sand Transport.

Pelaksanaan penyelesaian dengan metode numerik dilakukan dengan beberapa tahapan model yaitu persiapan data ukuran butir sedimen (grain size) domain kecil lokasi penelitian dan data hasil simulasi hidrodinamika berupa debit perairan atau fluks. Set-up nilai koefisien parameter model dengan memasukkan nilai parameter, time interval simulation, hingga running model. Ekstraksi data digunakan untuk melihat perubahan bed level dan pergerakan sedimen sebelum dan sesudah simulasi. 


\section{HASIL DAN PEMBAHASAN}

Kecepatan arus maksimum yang didapatkan sebesar $0,938 \mathrm{~m} / \mathrm{s}$ dan kecepatan arus minimum 0,001 $\mathrm{m} / \mathrm{s}$, sedangkan kecepatan arus rata-rata didapatkan sebesar 0,378 m/s. Hasil Pengolahan data model pada domain besar didapatkan kecepatan arus maksimum $0,735 \mathrm{~m} / \mathrm{s}$, arus minimum 0,166 m/s dan kecepatan ratarata sebesar $0,367 \mathrm{~m} / \mathrm{s}$. Pemodelan arus pada domain besar didapatkan hasil berupa kecepatan dan arah arus, kemudian akan dilakukan verifikasi data. Hasil verifikasi data model dan data lapangan didapatkan sebesar 7,26 \% .Dominansi sebaran arah arus pada lokasi pengukuran ADCP dapat dilihat pada diagram mawar arus (Current Rose) yang disajikan pada Gambar 3 menunjukkan bahwa arah arus lebih dominan mengarah ke arah barat laut dan timur laut

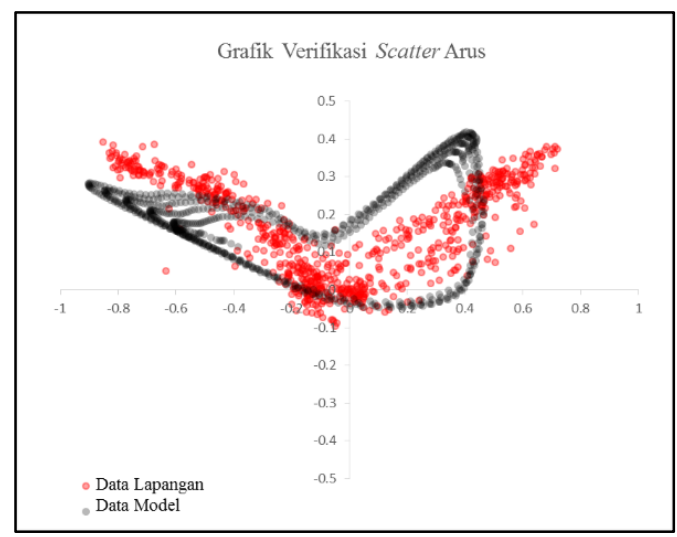

Gambar 2. Grafik Verifikasi Data Arus Lapangan dengan Data Model

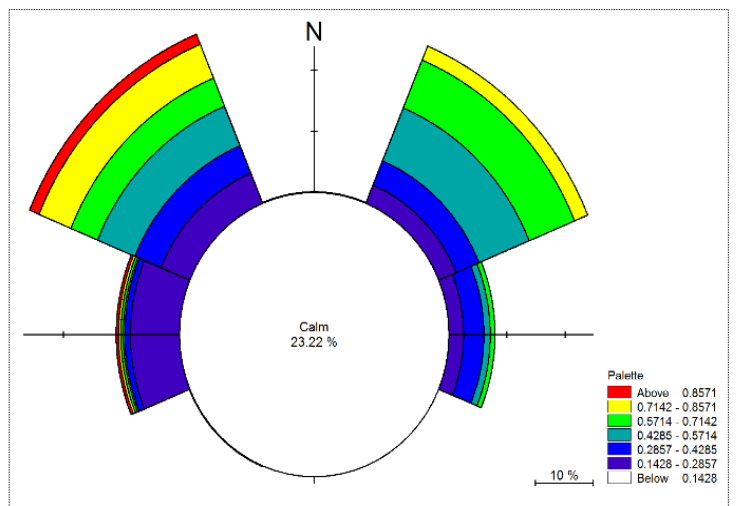

Gambar 3. Diagram Mawar Arus di lokasi ADCP

Nilai Formzhal berdasarkan pengolahan data lapangan didapatkan sebesar 4,167. Hasil tersebut diketahui bahwa tipe pasang surut perairan Karimunjawa adalah pasang surut harian tunggal (diurnal tide) yaitu terjadi satu kali pasang dan satu kali surut. Nilai Mean Sea Level yang didapatkan sebesar 13,48 cm, Highest High Water Level sebesar 13,96 cm, Lowest Lower Water Level 13,01 cm. Berikut merupakan hasil simulasi model beupa elevasi muka air laut dan pola arus pada saat kondisi pasang tertinggi ditunjukkan pada Gambar 4-5. 


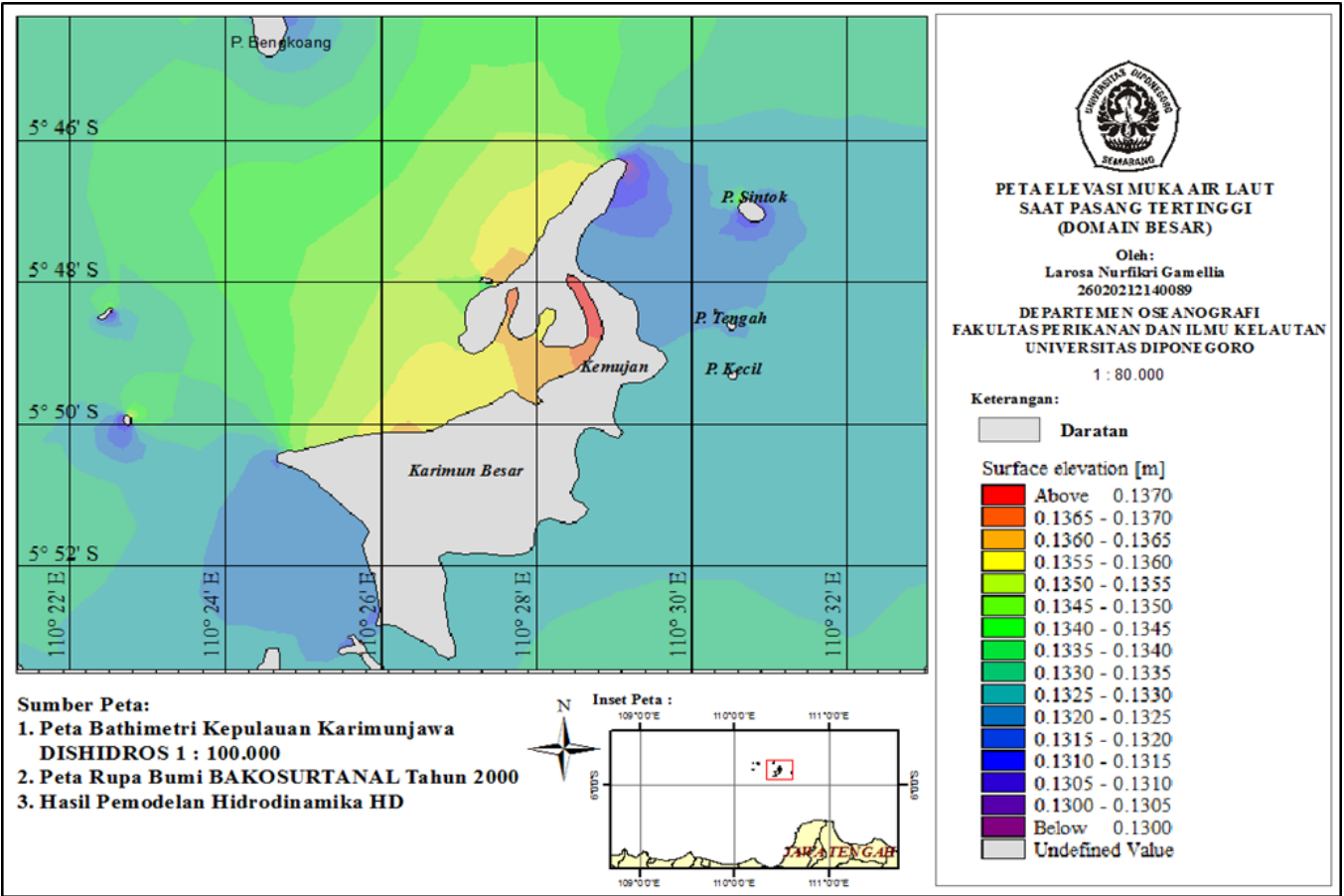

Gambar 4. Kondisi elevasi muka air pada saat kondisi pasang tertinggi (Domain Besar)

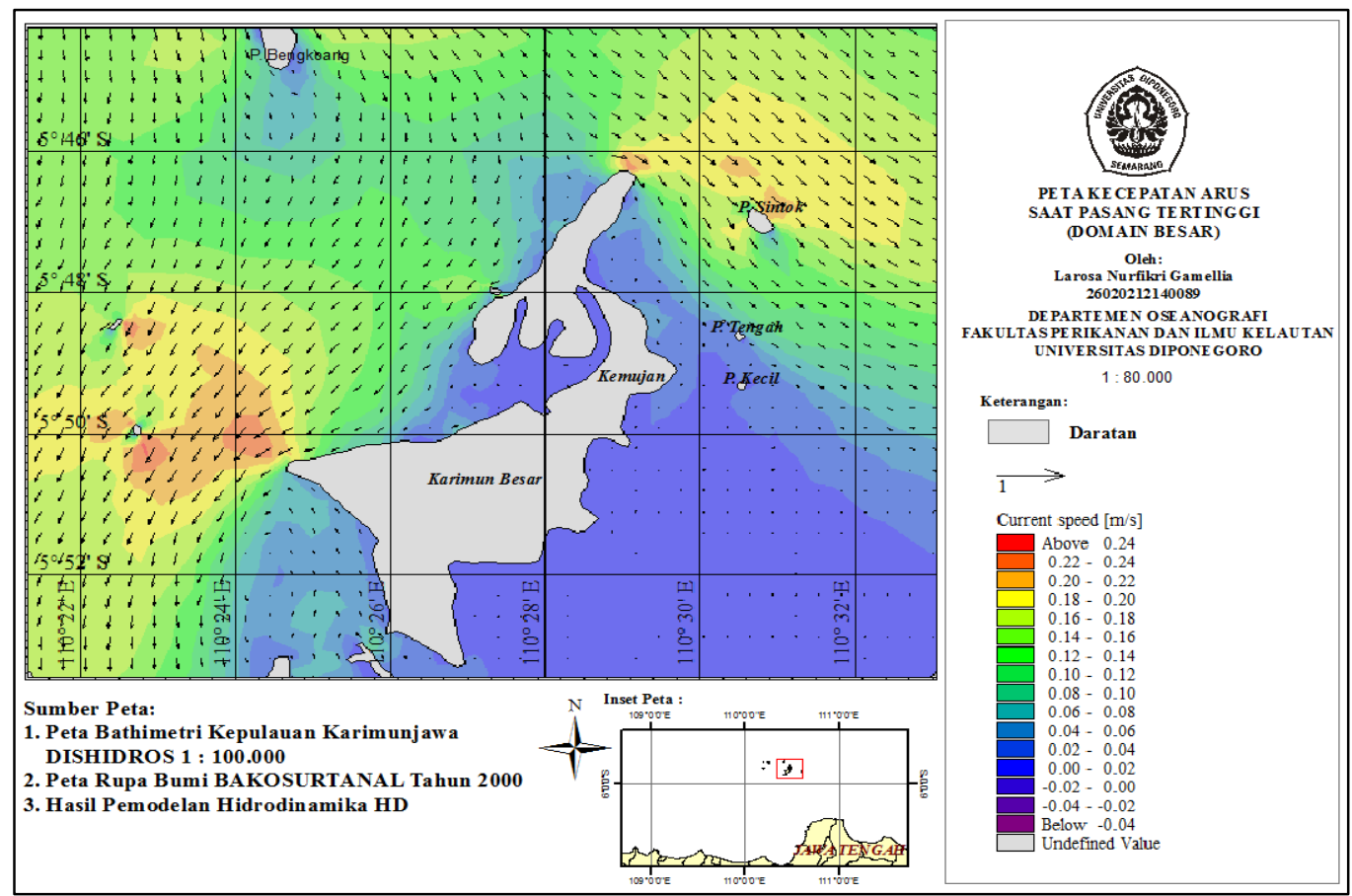

Gambar 5. Kondisi Kecepatan arus pada saat kondisi pasang tertinggi (Domain Besar)

Hasil simulasi model numerik MIKE 21 flow model hidrodinamika beupa elevasi muka air laut dan pola arus pada saat kondisi surut terendah ditunjukkan pada Gambar 6-7. 


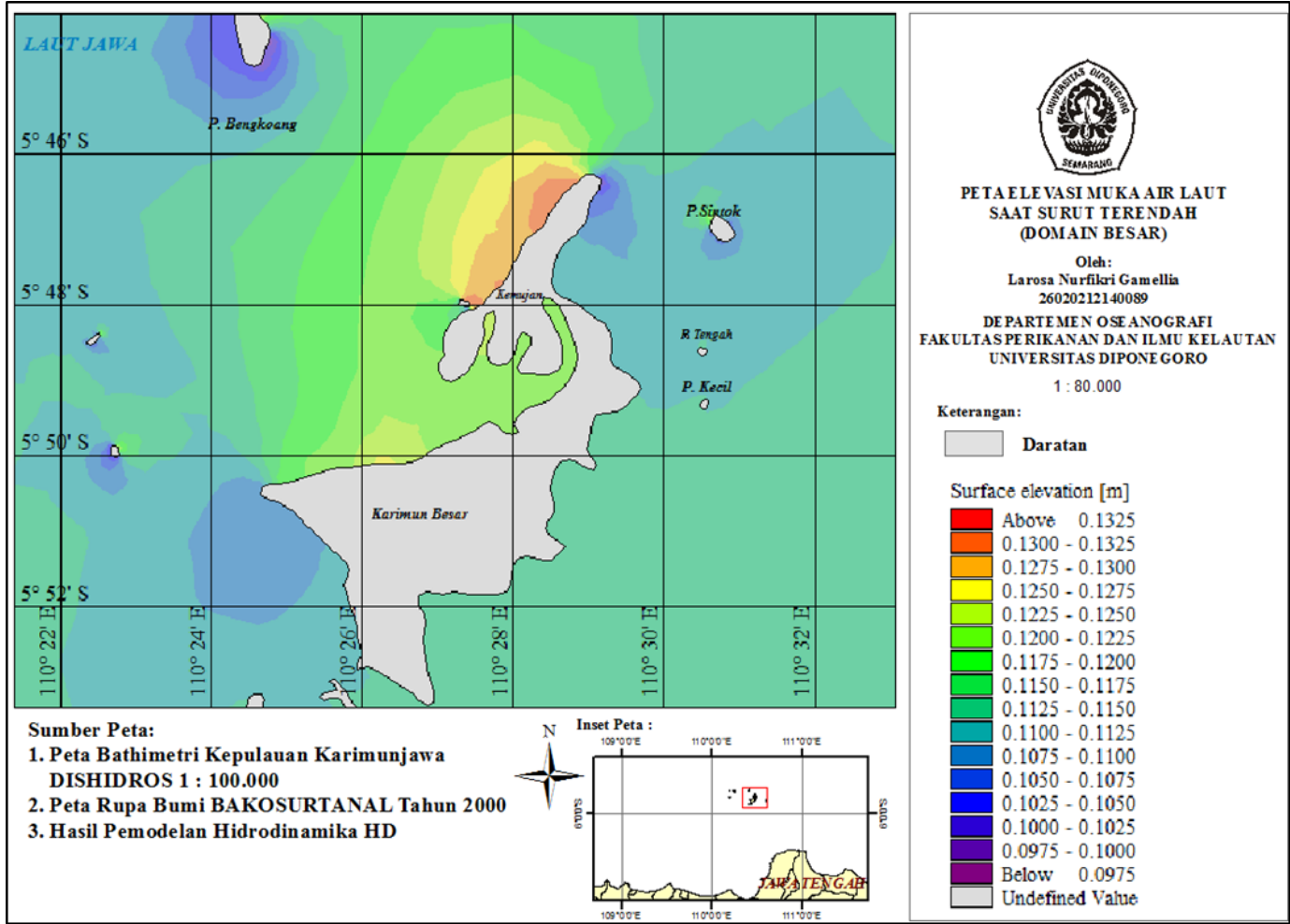

Gambar 6. Kondisi elevasi muka air pada saat kondisi surut terendah (Domain Besar)

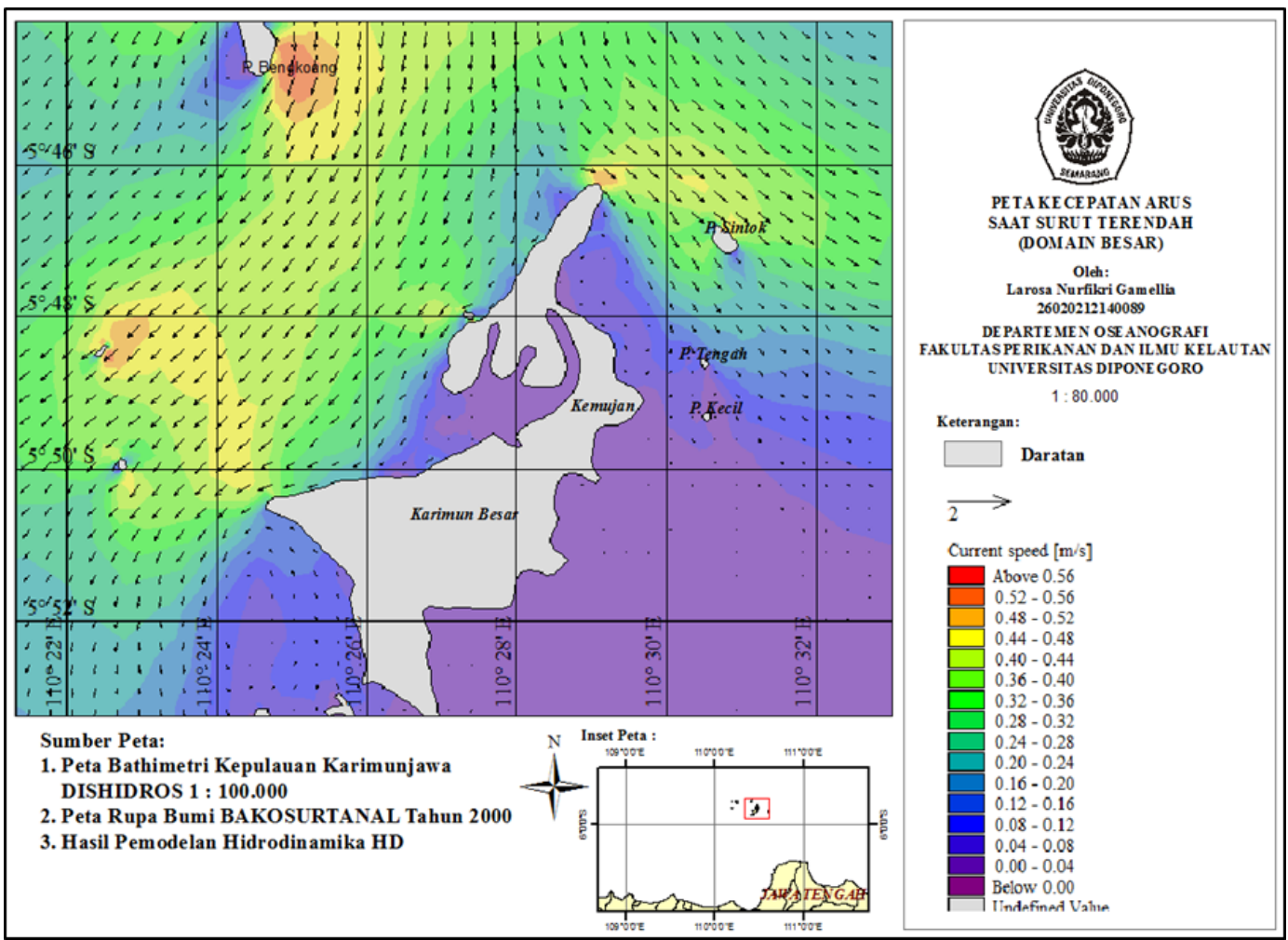

Gambar 7. Kondisi Kecepatan aruspada saat kondisi surut terendah (Domain Besar)

Berikut merupakan hasil simulasi model numerik MIKE 21 flow model hidrodinamika beupa elevasi muka air laut dan pola arus pada saat kondisi pasang tertinggi ditunjukkan pada Gambar 8-9. 


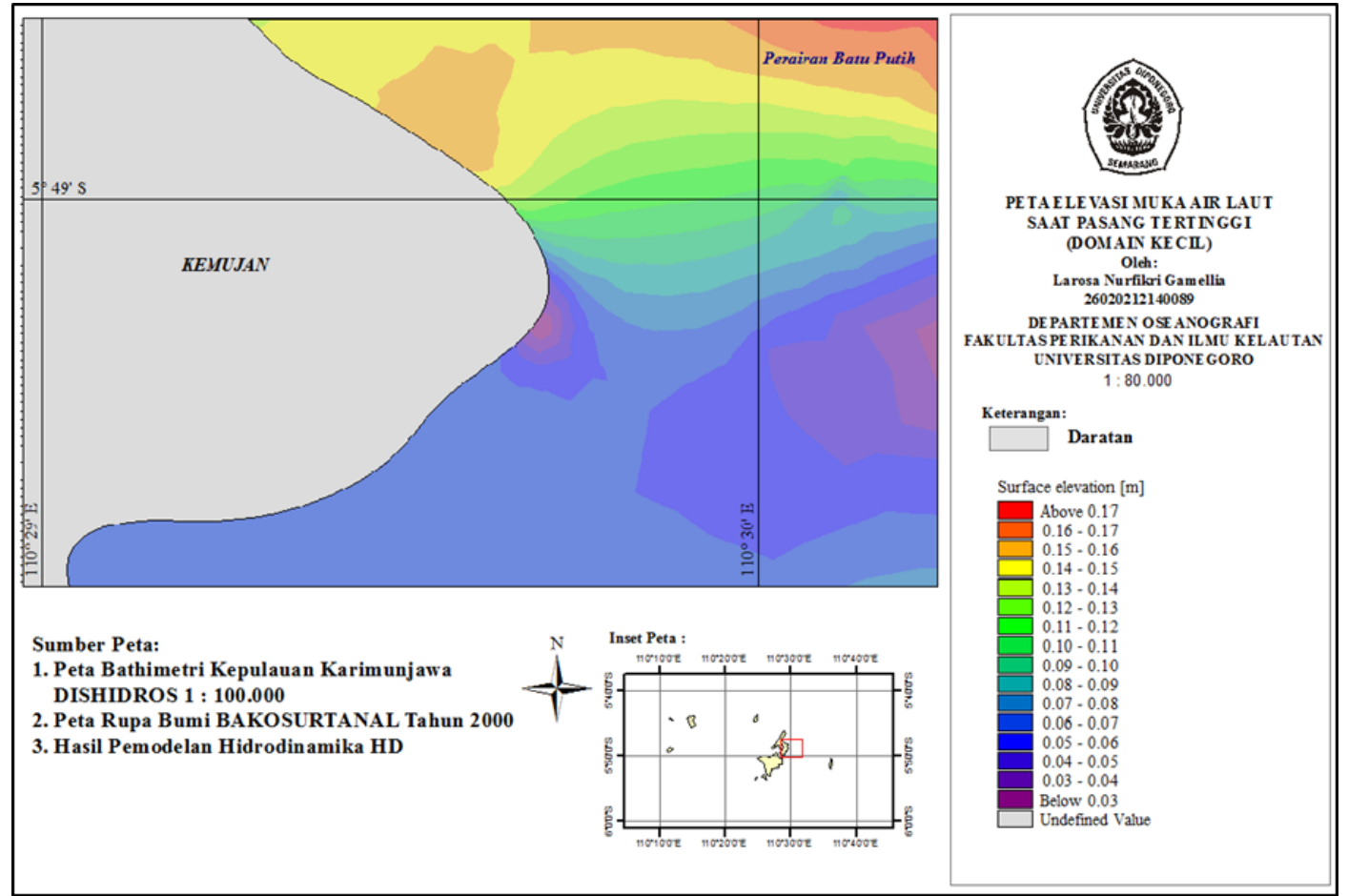

Gambar 8. Kondisi elevasi muka air pada saat kondisi pasang tertinggi (Domain Kecil)

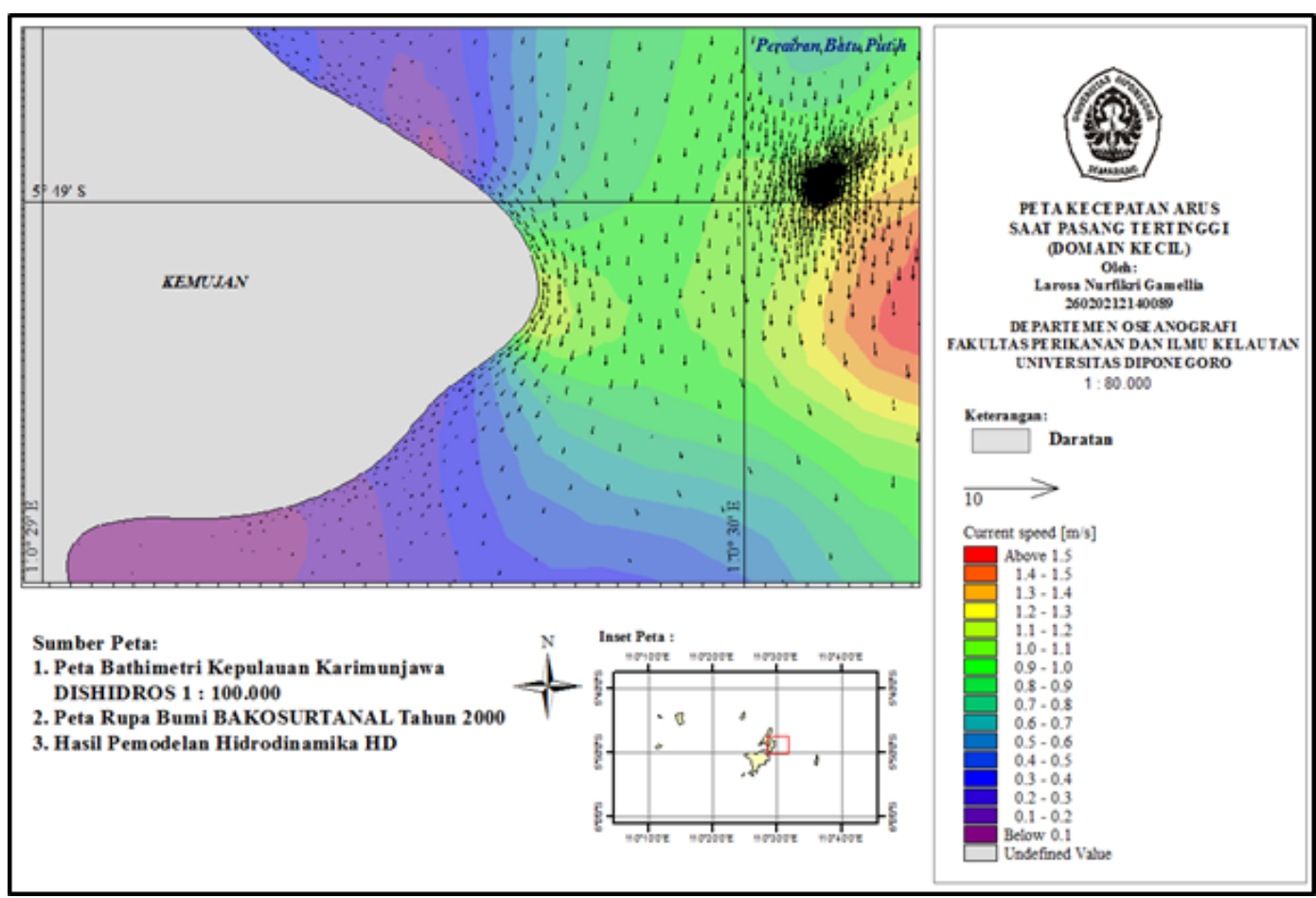

Gambar 9. Kondisi kecepatan arus pada saat kondisi pasang tertinggi (Domain Kecil)

Hasil simulasi model numerik MIKE 21 flow model hidrodinamika beupa elevasi muka air laut dan pola arus pada saat kondisi surut terendah ditunjukkan pada Gambar 10-11. 


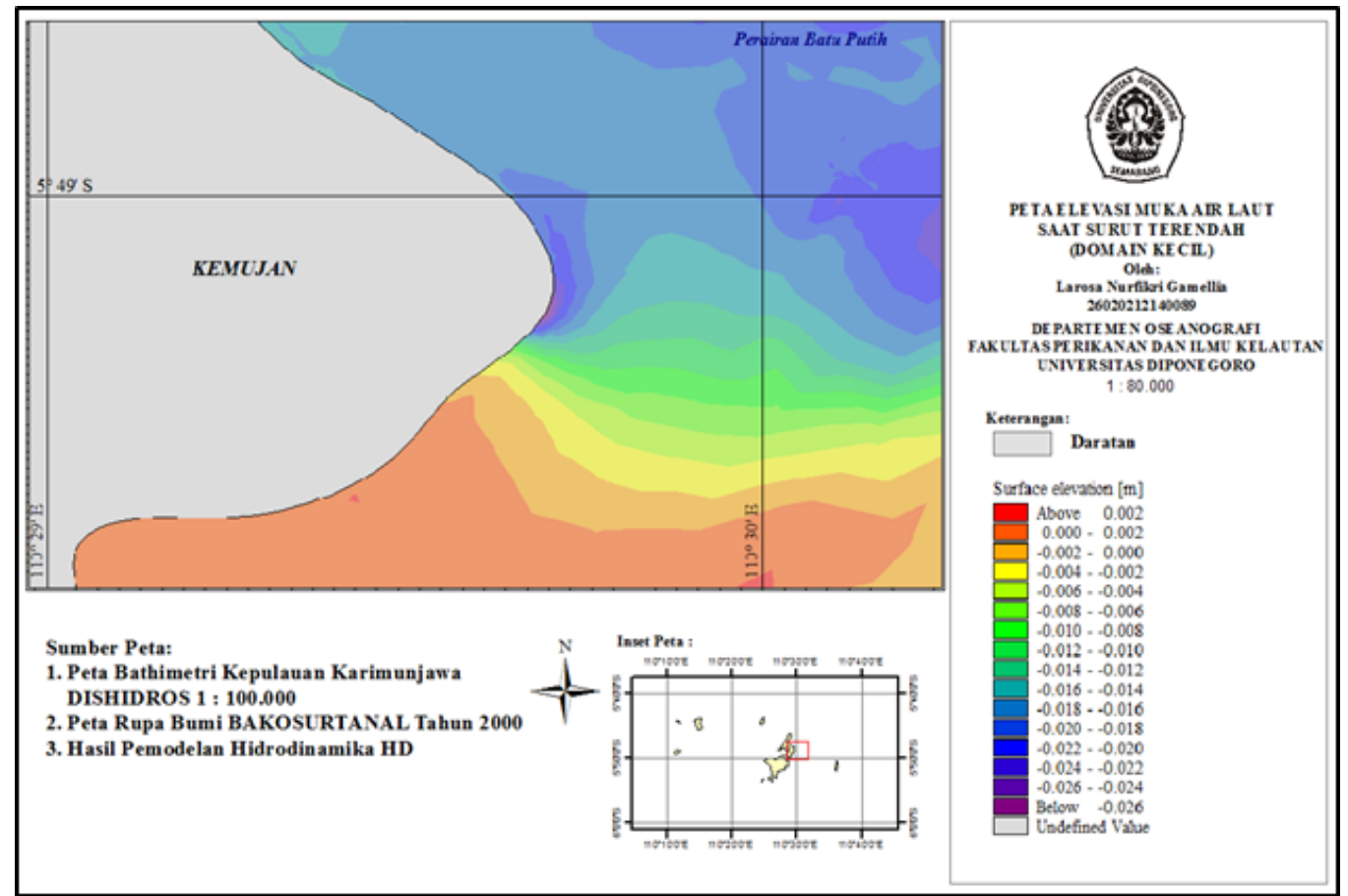

Gambar 10. Kondisi elevasi muka air pada saat kondisi surut rendah (Domain Kecil)

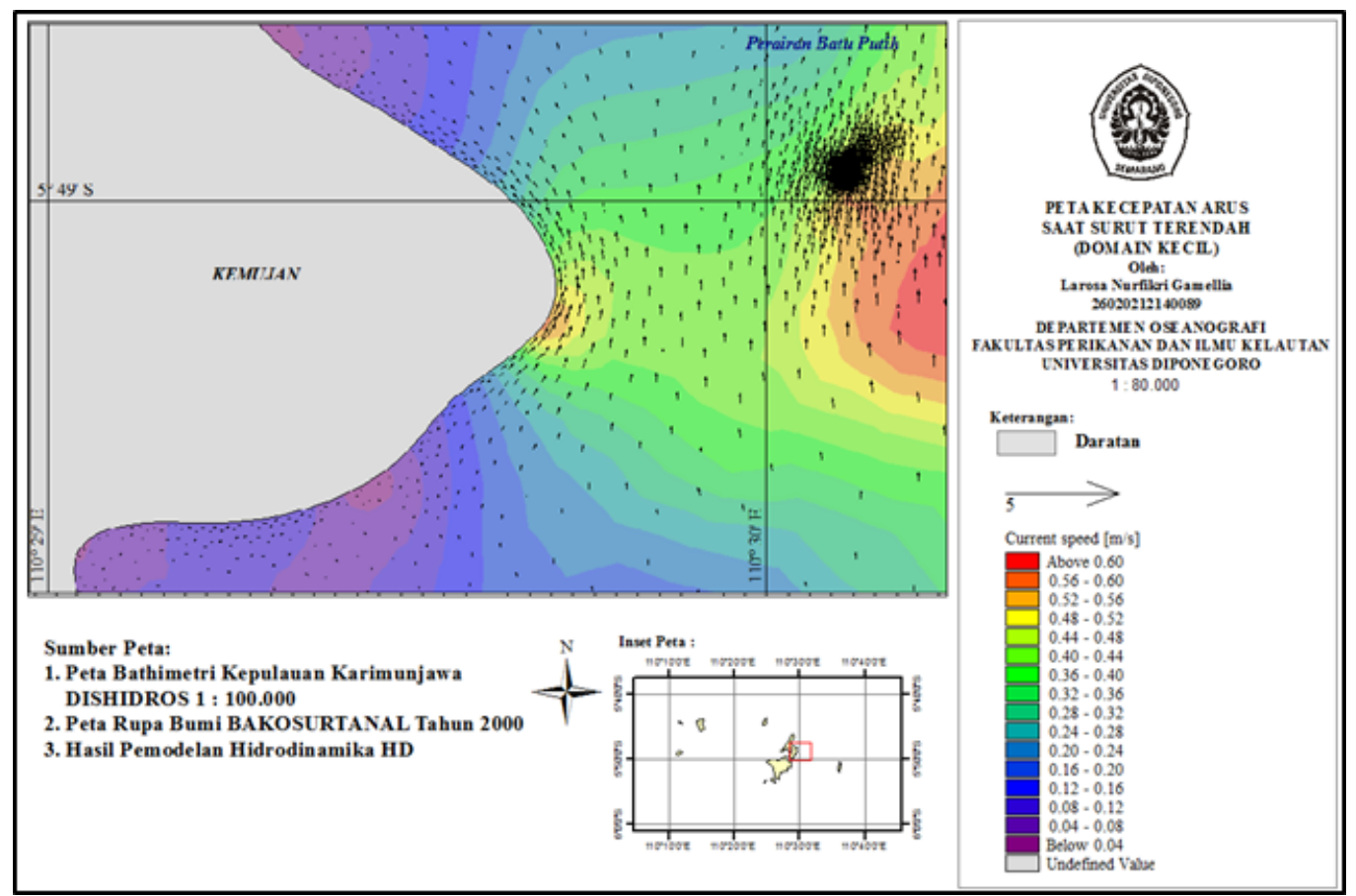

Gambar 11.Kondisi kecepatan arus pada saat kondisi surut rendah (Domain Kecil)

\section{Hasil Model Sedimen Dasar}

Berdasarkan hasil analisa ukuran butir ditunjukkan bahwa sedimen dasar di perairan Batu Putih Karimunjawa didominasi oleh pasir dengan persentase (\%) pasir 98,48 \%; lanau 1,14\%; lempung 0,38\%. Ukuran butir didapatkan dengan nilai grain diameter $\left(D_{50}\right)$ yaitu sebesar $0,3 \mathrm{~mm}$. Analisa transportasi sedimen kemudian dilakukan menggunakan simulasi pemodelan numerik. Perubahan sedimentasi di lokasi kajian dapat diamati dengan membuat beberapa potongan melintang pada sekitar bangunan.Hasil dari potongan melitang pada gambar menunjukkan adanya perubahan kedalaman batimetri sebelum maupun sesudah simulasi di area bangunan terumbu buatan (artificial reefs) yang dipresentasikan melalui grafik. Potongan melintang tersebut terbagi dalam beberapa bagian, yaitu potongan I-I, potongan II-II dan potongan III-III. Pada potongan saat sebelum maupun sesudah simulasi terdapat perubahan, yaitu pertambahan kedalaman (erosi) dan sedimentasi yang ditunjukkan Gambar 12-13. 


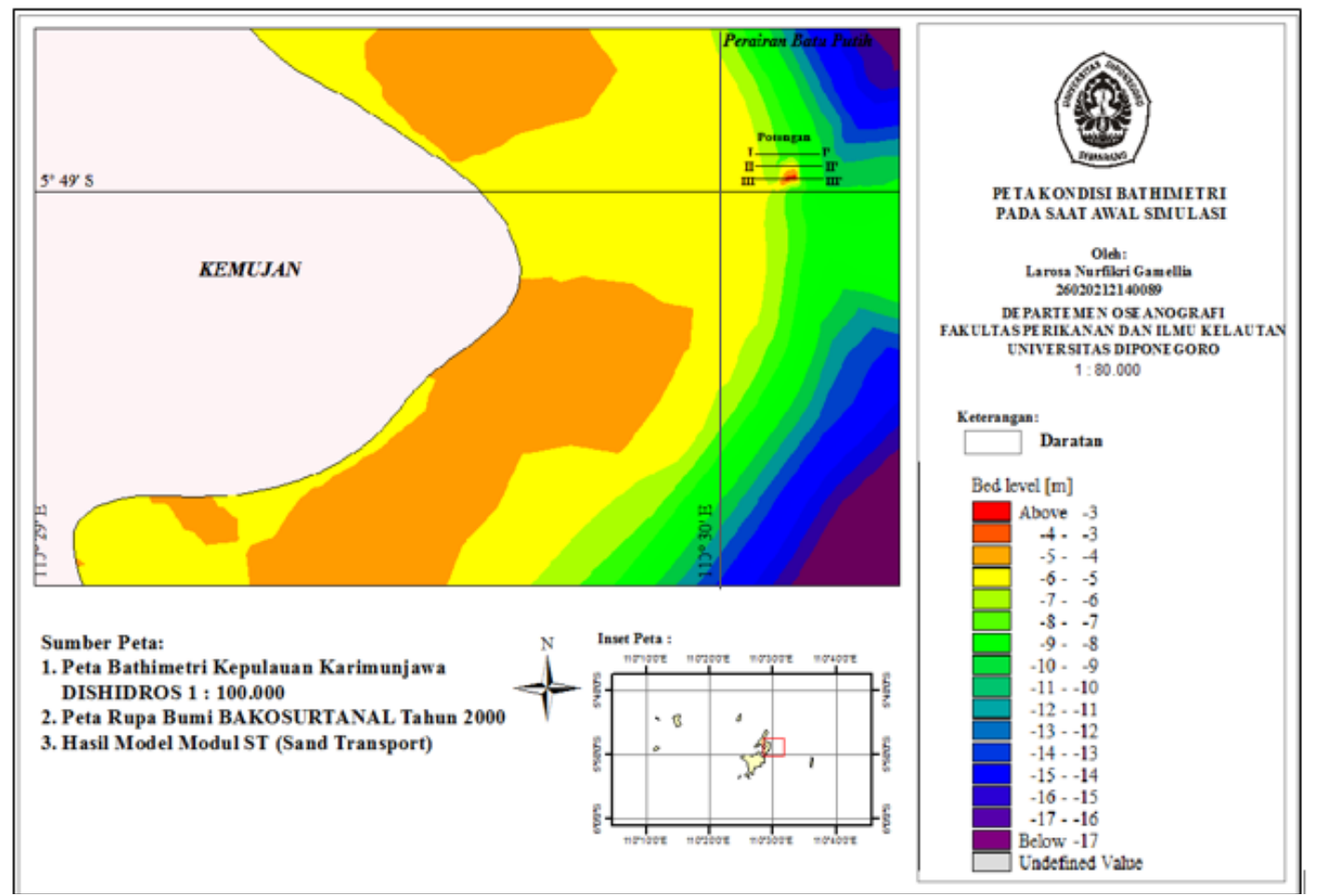

Gambar 12. Kondisi perubahan bathimetri (Bed Level) pada saat awal simulasi

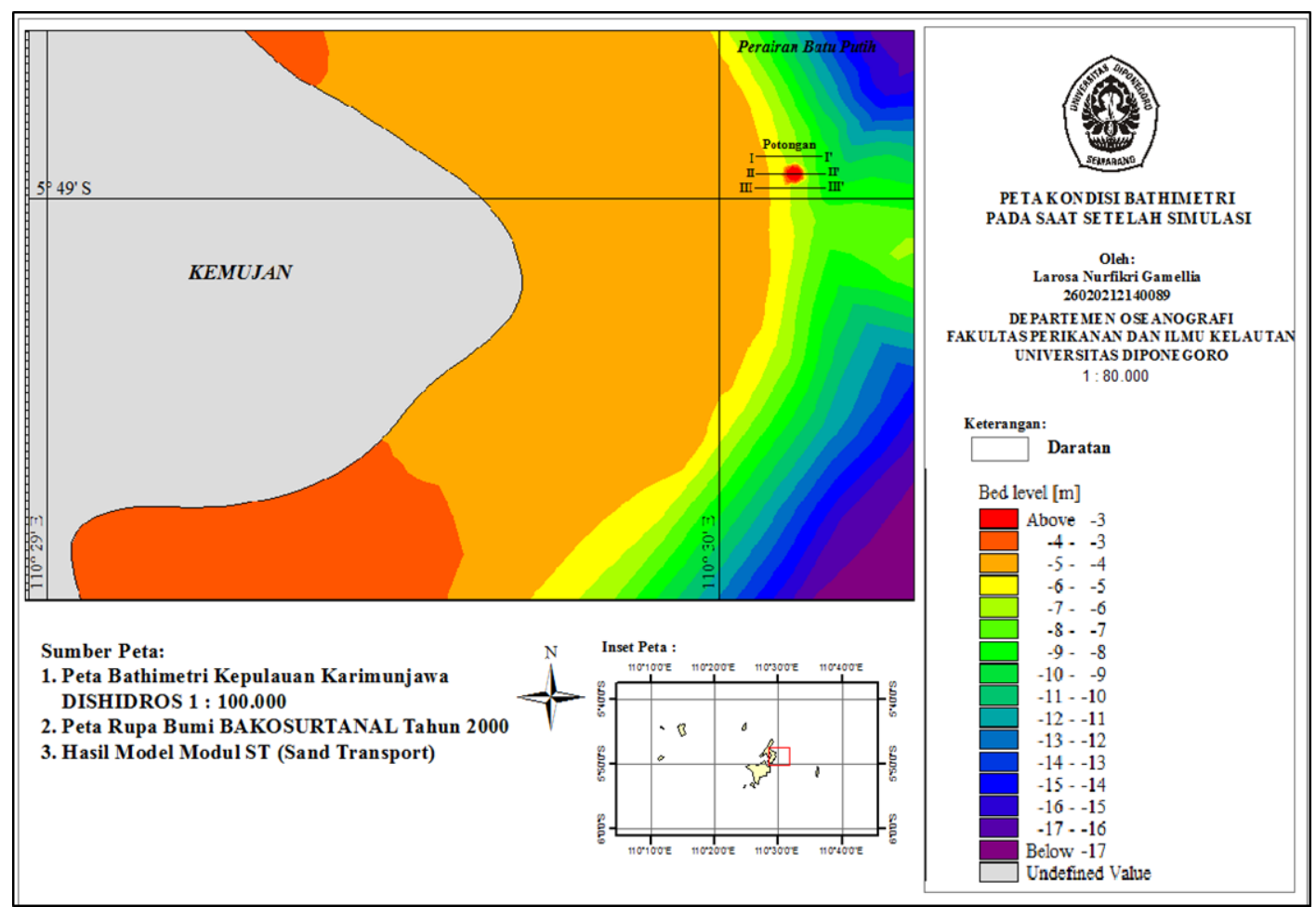

Gambar 13. Kondisi perubahan batimetri (Bed Level) pada saat akhir simulasi

Berikut merupakan grafik hasil dari kondisi arus dan kondisi batimetri pada potongan melintang sebelum dan setelah simulasi model ditunjukkan pada Gambar 14. 


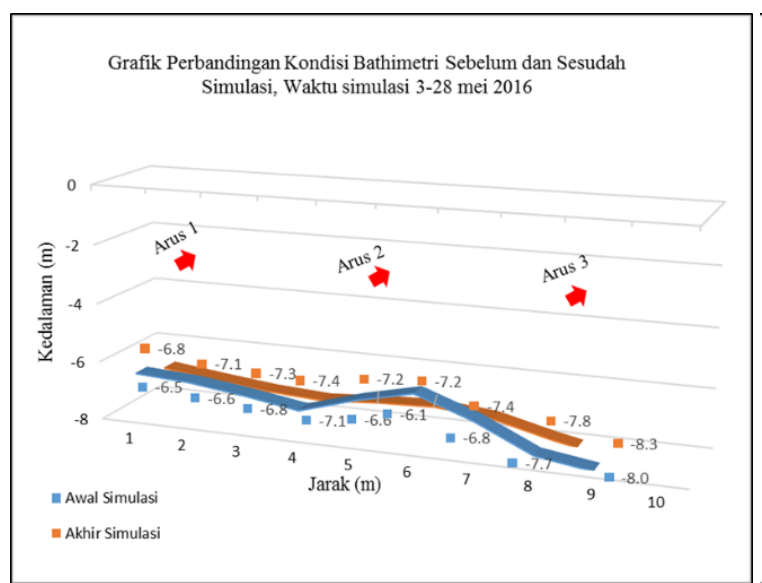

(a). Potongan I-I'

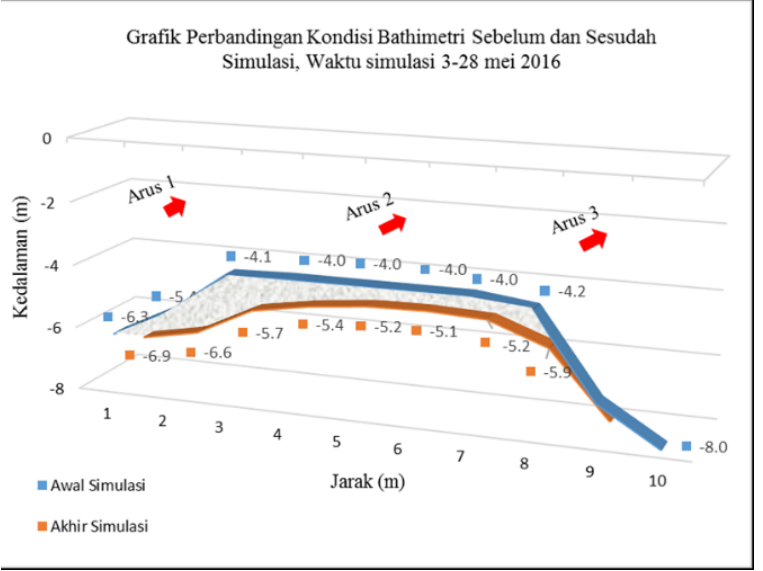

(b). Potongan II-II'

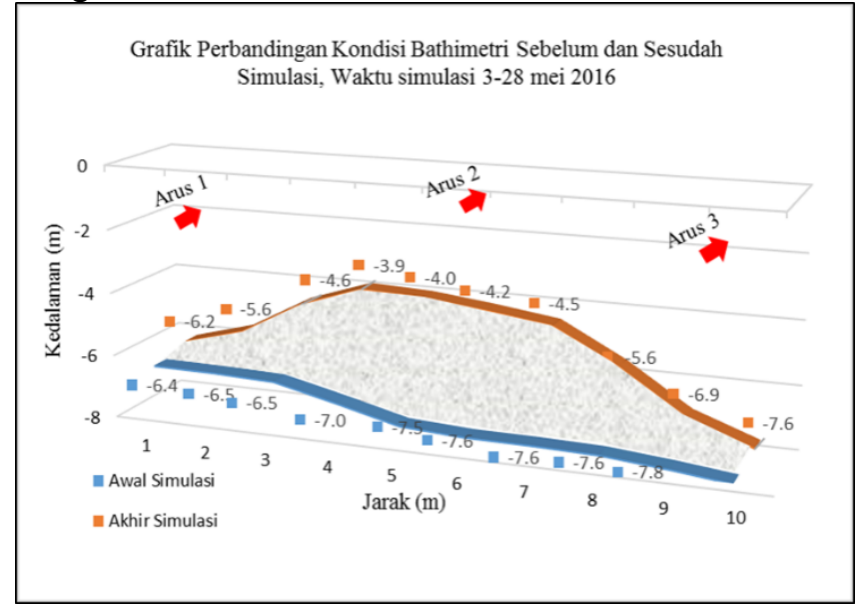

(c). Potongan III-III'

Gambar 14. Grafik Potongan Melintang Pengamatan Perubahan Kedalaman (Bed Level Change)

Tabel 3. Kondisi Arus pada Potongan Melintang

\begin{tabular}{llll}
\hline Keterangan & Arus 1 & Arus 2 & Arus 3 \\
\hline Potongan I-I' & 0,587 & 0,590 & 0,593 \\
Potongan II-II' & 0,607 & 0,650 & 0,640 \\
Potongan III-III' & 0,656 & 0,698 & 0,723 \\
\hline
\end{tabular}

(Sumber: Penelitian 2016)

\section{Pembahasan}

Kecepatan arus rata-rata yang didapatkan pada titik pengukuran lapangan ADCP sebesar $0,378 \mathrm{~m} / \mathrm{s}$ dengan kecepatan arus maksimum $0,9388 \mathrm{~m} / \mathrm{s}$ dan kecepatan arus minimum $0,001 \mathrm{~m} / \mathrm{s}$. Kemudian dilakukan verifikasi data dengan error sebesar 7,26 \%, data yang bertujuan untuk melihat perbandingan antara data arus yang didapat dari hasil simulasi software dengan arus pengambilan data lapangan. Daerah domain kecil hasil dari simulasi flow model memperlihatkan pola pergerakan arus pada setiap kondisi berbeda pasang tertinggi dan surut terendah. Arus rata-rata pada saat pasang sebesar $0,886 \mathrm{~m} / \mathrm{s}$ sedangkan pada saat surut sebesar 0,392 $\mathrm{m} / \mathrm{s}$. Perbedaan dikarenakan adanya perubahan elevasi muka air laut. Arah arus pasang surut ini sangat dipengaruhi oleh kondisi lingkungan atau topografi setempat. Pada diagram mawar angin disajikan bahwa arus pada pengukuran ADCP bergerak dominan menuju barat laut dan timur laut. Gerakan arus dalam hal ini berarti cenderung bergerak dari darat ke arah laut, berkaitan dengan pengukuran yang dilaksanakan di daerah dekat pantai.

Analisa transportasi sedimen dilakukan untuk mengetahui adanya perubahan dasar perairan, baik erosi maupun sedimentasi. Analisa dilakukan dengan membuat potongan melintang kemudian melakukan perbandingan dasar perairan bed level (Gambar 12-13) saat sebelum dan setelah simulasi pada 3 - 28 Mei 2016. Hasil potongan melintang disajikan dalam bentuk grafik (Gambar 14) yang merupakan gambaran dari kondisi bangunan artficial dapat dikategorikan sebagai struktur pemecah gelombang tipe tenggelam. Struktur ini dapat menyebabkan adanya perubahan dari kecepatan dan arah arus yang membawa partikel. 
Potongan melintang I-I' (Gambar 14 a) terlihat mengalami perubahan kedalaman (erosi) pada jarak 4 - 8 meter sepanjang garis dan potongan melintang II-II' (Gambar 14 b) mengalami perubahan kedalaman (erosi) sepanjang garis potongan melintang yang terjadi selama proses simulasi, sedangkan pada potongan melintang III-III' (Gambar 14c) mengalami penumpukan material sedimen (sedimentasi) pada rentang jarak $10 \mathrm{~m}$. Terlihat juga untuk kondisi arus pada saat dan setelah simulasi di sekitar struktur bangunan mengalami perubahan kecepatan arus, hal ini terjadi karena adanya pengaruh dari stuktur tersebut. Dinamika arus tersebut menyebabkan terjadinya transportasi partikel sedimen, dimana pada saat arus yang membawa partikel mena penghalang (struktur bangunan artificial). Partikel akan mengendap pada sisi lain bangunan (potongan melintang III-III'), terdapat partikel sedimen yang tergerus dan terbawa arus (potongan melintang I-I' dan potongan melintang II-II'). Fluida (massa air) dalam hal ini berperan dalam proses transportasi dan pengendapan sedimen, yang mana fluida tersebut mentransfer energi pada partikel-partikel sedimen. Fluida tersebut mentransfer energi dalam jumlah yang cukup sehingga dapat membuat partikel-partikel tersebut terlepas dan mengendap

\section{KESIMPULAN}

Berdasarkan penelitian yang telah dilakukan, didapatkan hasil perubahan kedalaman pada saat sebelum dan setelah simulasi pada daerah bangunan artificial. Dinamika pergerakan arus yang terjadi menyebabkan transportasi partikel sedimen, fluida tersebut mentransfer energi pada partikel-partikel sedimen. Potongan melintang I-I' dan potongan melintang II-II' mengalami perubahan kedalaman (erosi) sepanjang garis potongan melintang, sedangkan pada potongan melintang III-III' mengalami penumpukan material sedimen (sedimentasi) pada rentang jarak $10 \mathrm{~m}$.

\section{Daftar Pustaka}

Balitbang, 2003. Penelitian Identifikasi dan Penyelamatan Ekosistem TerumbuKarang Bagi Nelayan Kecil di Karimunjawa. Badan Penelitian danPengembangan Propinsi Jawa Tengah.

Juhasz, A., E. Ho, E. Bender dan P. Fong. 2010. Does Use of Tropical Beaches by Tourist and Island Resident Result in Damage to Fringing Coral Reef ACase Study in Moorea French Polynesia. Mar. Poll. Bull., 60: $2251-2256$.

Nontji, A. 1993. Laut Nusantara. Penerbit Djambatan, Jakarta.

Rifardi. 2012. Ekologi Sedimen Laut Modern. UR Press: Pekanbaru, $167 \mathrm{hlm}$.

Sugiyono. 2009. Metode Penelitian Kuantitatif, Kualitatif, dan R\&D. Alfabeta, Bandung.

Umardiono, Andy. 2011. Pengembangan Obyek Wisata Taman Nasional LautKepulauan Karimunjawa., 24 (3): 192-201.

Yusuf, Muh, G. Handoyo, Muslim, S. Y. Wulandari., dan H. Setiyono. 2012. Karakteristik Pola Arus Dalam Kaitannya dengan Kondisi Kualitas Perairan dan Kelimpahan Fitoplankton di Perairan Kawasan Taman Nasional Laut Karimunjawa. Buletin Oseanografi Marina., 1: 63-74. 